Relations industrielles

Industrial Relations

\title{
Corporate Voluntarism and Human Rights
} The Adequacy and Effectiveness of Voluntary Self-Regulation Regimes

\section{Volontarisme d'entreprise et droits humains : la pertinence et l'efficacité des régimes d'autorégulation volontaire Voluntarismo corporativo y derechos humanos: la pertinencia y eficacia de los regímenes voluntarios de auto-regulación}

\section{Penelope Simons}

Volume 59, numéro 1, hiver 2004

Équité, efficience, éthique ? La régulation sociale de l'entreprise mondialisée

URI : https://id.erudit.org/iderudit/009129ar

DOI : https://doi.org/10.7202/009129ar

Aller au sommaire du numéro

Éditeur(s)

Département des relations industrielles de l'Université Laval

ISSN

0034-379X (imprimé)

1703-8138 (numérique)

Découvrir la revue

Citer cet article

Simons, P. (2004). Corporate Voluntarism and Human Rights: The Adequacy and Effectiveness of Voluntary Self-Regulation Regimes. Relations industrielles / Industrial Relations, 59(1), 101-141. https://doi.org/10.7202/009129ar
Résumé de l'article

En l'absence de responsabilité légale interne et internationale des entreprises transnationales en matière d'abus au plan des droits humains dans leurs activités outre-mer, les gouvernements, les entreprises et les ONG ont encouragé le développement et la mise en oeuvre de régimes d’autorégulation volontaire. Cependant, les détracteurs de ces mesures volontaires soutiennent que leur capacité de réglementer l'activité des entreprises et de solutionner les enjeux qui y sont liés en termes de droits humains est demeurée prévenir une certaine complicité des entreprises dans des situations de violation évidente des droits humains, reliées à leurs activités prevenir une certaine complicité des entrepriseses dans conflits et sous des régimes répressifs.

L'étude recense et évalue les codes et les politiques de quatre entreprises pétrolières multinationales, en plus des codes développés par l'industrie, les organismes intergouvernementaux et les initiatives des multidétenteurs d'intérêts. Elle examine aussi les pratiques d'entreprises associées à l'emploi de ces instruments, laissant entrevoir des problèmes importants au plan de leur nature volontaire, de leur langage, de leur contenu en termes de droits humains et des mécanismes d'acquiescemen

La configuration des codes et des politiques étudiés varie beaucoup, en passant d'une liste de principes généraux à des normes plus précises, et comporte parfois des exigences de mise en oeuvre et des mesures volontaires de suivi. Peu de ces instruments traitent suffisamment des enjeux en termes de droits humains. Seulement les Nations Unies avec le développement de leurs « Normes sur la abordé dans le détail l'enjeu de la complicité dans les abus au plan des droits humains, et toutes les normes, sauf colles des Nations Unies, sont formulées dans un langage permissif. De plus, aucun de ces codes et aucune de ces politiques, excluant les normes de l'ONU, ne présentent des mécanismes de respect efficaces.

En jetant un coup d'oeil sur les pratiques qui se développent chez les multinationales pour rendre compte de leur performance en matière de droits humains et sociaux, on constate que peu d'entreprises semblent avoir mis au point un cadre de comptabilité sociale transparente et fiable selon des procédures et une methodologie qui offrent une garantie dexactitude au plan de la cueillette de donnees liees aux droits humains. Souvent, il n'existe aucune divulgation du processus qui encadre la selection et la consultation des contenu d'un rapport en particulier, ou bien de la manière dont les décisions sont prises sur ce qui entre ou n'entre pas dans un rapport. Enfin, on observe une tendance marquée chez les entreprises transnationales à donner un bilan positif du progrès et de $l$ la performance des entreprises, nonobstant la divulgation sporadique de leurs forces et de leurs faiblesses.

En ce qui concerne la question de la reddition des comptes en matière de performance sociale, les Lignes directrices de la Global Reporting Initiative (GRI) pour le reporting développement durable de 2002 constituent dans l'ensemble un développement encourageant. Elles possèdent une légitimité dans la communauté des affaires et des ONG due à la large consultation dont elles ont fait l'objet au moment de leur elaboration et elles prévoient une séverité croissante au plan des normes de divulgation qui press fournissent pas d'indicateurs spécificues pour un site particulier d'exploitation ou pour un environnement d'activités d'une entreprise en particulier. Deuxièmement, l'absence d'élaboration d'indicateurs de droits humains engendre une situation insatisfaisante en permettant aux compagnies qui font rapport d'éviter de traiter des enjeux fondamentaux des droits humains liés à leurs activités et de prétendre que leur rapport est conforme aux directives. Enfin, une vérification indépendante n’est pas exigée pour qu'un rapport soit considere en accord avec les directives.

Les pratiques courantes de vérification sont aussi l'objet de préoccupations sérieuses. Tout comme dans le cas de la divulgation sociale, il n'y a pas de normes universelles acceptées pour fins de vérification sociale, quoique des normes volontaires privées soien en élaboration. Sans normes obligatoires de vérification, les mandats de vérification sont donnés par les multinationales elles-mêm relation avec les activités des entreprises ne sont pas abordées sauf à la discrétion des multinationales elles-mêmes. Elles ne sont probablement pas soulevées par les vérificateurs dans tout rapport soumis au public.

Les rapports de vérification ont tendance à manquer de transparence au plan des procédures et de la méthodologie de cueillette et de vérification de l'information. L'impartialité des vérificateurs devient une autre préoccupation majeure puisque plusieurs entreprises privées de consultation et de vérification fournissent également des services-conseils aux multinationales dont elles assurent la vérification des livres. La fiabilite des rapports est en plus minee due au fait que la plupart des entreprises de vérification et de consultation ne possèdent pas l'expertise nécessaire en matière de cueillette et de divulgation d'information sur les droits humains. Les normes des Nations Unies mises à part, les régimes actuels d'autorégulation, de par leurs dispositions inadéquates et permissives, plus inaptes à créer une reddition réelle de comptes en matière de droits humains de la part des entreprises transnationales oeuvrent dans des zones de conflits ou sous des régimes répressifs.

De tels codes et politiques pourraient être molifiés de facon ingpan De tels codes et politiques pourraient être modifiés de façon importante en précisant des obligations bien définies en matière de droits umains, une divulgation contraignante et des normes obligatoires de vérification, de même que des exigences de contrôle indépendant. Cependant, il ne faut pas s'attendre à ce que de telles réformes soient adéquatement abordées par le secteur privé Le volet volontaire de ces pratiques et de ces outils demeurera probablement problématique là où les obligations entrent en conflit avec des préoccupations de profitabilité et de concurrence à l'échelle mondiale. C'est pourquoi, en plus d'encourager r'amélioration de ces codes, il serait egalement important d'exercer une pression sur les gouvernements pour qu'ils adoptent a l'interne des mesures fournissent un support aux initiatives de l'ordre de celles des normes des Nations Unies qui paveront les fondements d'une réglementation à l'échelle internationale.
Tous droits réservés @ Département des relations industrielles de l'Université Laval, 2004
Ce document est protégé par la loi sur le droit d'auteur. L’utilisation des services d’Érudit (y compris la reproduction) est assujettie à sa politique d'utilisation que vous pouvez consulter en ligne.

https://apropos.erudit.org/fr/usagers/politique-dutilisation/ 


\title{
Corporate Voluntarism and Human Rights
}

\section{The Adequacy and Effectiveness of Voluntary Self-Regulation Regimes}

\author{
Penelope Simons
}

In response to increasing public concern over the accountability of transnational corporations (TNCs) for violations of human rights in the states in which they operate, governments, corporations and NGOs have promoted the development and implementation of voluntary self-regulatory regimes. However, TNC practices under these regimes call into question their adequacy and effectiveness in preventing complicity in egregious violations of human rights by corporations operating in conflict zones and repressive regimes. This article reviews and assesses the language, human rights content and compliance mechanisms of the voluntary policies and/or codes developed by a number of corporations, industry groups, intergovernmental organizations and multistakeholder initiatives, as well as associated corporate practices. The analysis shows that these voluntary regimes are flawed and inadequate, and therefore unable to ensure that TNCs are not complicit in human rights violations in their extraterritorial activities.

- Simons, P., School of Social Sciences and Law, Oxford Brookes University, Oxford, U.K., psimons@brookes.ac.uk.

- This paper is drawn from a larger study that is being conducted in collaboration with Professor Audrey Macklin of the Faculty of Law, University of Toronto and Georgette Gagnon of the Organisation for Security and Cooperation in Europe, and is sponsored by the Law Commission of Canada and SSHRC, with institutional support from the Faculty of Law, University of Toronto. The author would like to thank Audrey Macklin and Georgette Gagnon for their comments, suggestions and editorial input on earlier drafts and the anonymous RI/IR referees for their very helpful comments. She would also like to thank Dr. Adila Abusharaf and Cameron Hutchison for their excellent research assistance. A shorter version of this paper was published in the 2002 proceedings of the Annual Conference of the CCIL. 
There is a growing international concern about the accountability transnational corporations and other business entities (TNCs) for egregious violations of human rights committed by security forces, or host state military forces, in the protection or facilitation of business activity. Allegations of complicity ${ }^{1}$ in forced displacement, extrajudicial killings, disappearances, rape and abduction, the use of forced labour and violent repression of peaceful protests have been made against companies, particularly in the extractive sector, operating in a commercial relationship with host governments with a poor human rights record and/or in the context of a civil war.

In Burma (Myanmar), for example, oil companies, including the U.K.-based Premier Oil have been accused of complicity in human rights abuses including forced displacement and forced labour committed by members of the Burmese military. ${ }^{2}$ In the case of Premier Oil, Burmese military forces were hired by the company and its joint venture partners to protect the Yetagun pipeline and company employees (Macalister 2000; Osborn 2001). ${ }^{3}$ In Sudan, in the course of an ongoing and brutal civil war, government military forces and government-sponsored militia have been protecting the oil exploration and development areas from rebel attacks. They have done this by forcibly displacing local civilian populations using helicopter gunships, crude bombs dropped from Antonov bombers and by further terrorizing these populations through murder, rape, the abduction of women and children and the burning of villages (Harker 2000; Gagnon and Ryle 2001; Human Rights Watch 2003b). Talisman Energy Inc., a Canadian company, which was operating in the Upper Western Nile region of South Sudan from 1998 to 2003 as partner in the Greater Nile Petroleum

1. Complicity has been defined as acts or omissions by a company that provides material assistance or encouragement to the perpetrators of human rights abuses where the company knew or ought to have known that its conduct would provide such assistance or encouragement. In addition, complicity can include participation in a commercial undertaking where the company knew or ought to have known that acts committed by one of its business partners "would be a probable consequence of carrying out the commercial undertaking with that party" (Gagnon, Macklin and Simons 2003: 126-130; see also Clapham and Jerbi 2001).

2. The widespread practice of forced displacement of minority populations and forced labour, including forced child labour by authorities and members of the Burmese military has been documented and criticized by the UN, the International Labour Organization (ILO), the U.S. government and numerous human rights NGOs (UN 2000; UN 2002a; U.S. Department of State 2003; Human Rights Watch 2003a).

3. Premier Oil which recently sold its stake 26.67 per cent interest in the Yetagun gas field and pipeline project was active in Burma from 1990 to 2002 and operated in partnership with Petronas Carigali Myanmar Inc., PTTEP International Limited, Nippon Oil Exploration (Myanmar) Limited, the Burmese state owned Myanmar Oil and Gas Enterprise. 
Operating Company (GNPOC), has been accused of complicity in these human rights abuses. ${ }^{4}$

Similar allegations have been leveled against companies such as British Petroleum plc. (BP), Royal Dutch/Shell Group (Shell), and other TNCs. ${ }^{5}$ In relation to its operations in Colombia, BP was implicated in the grave violations of human rights, including extrajudicial murder, torture and "disappearances" committed by its hired security forces, which included members of the Colombian military (Human Rights Watch 1998). Shell was accused of complicity in the brutal repression of local protesters by the Nigerian military that culminated in the trial and execution of writer/activist Ken Saro Wiwa and nine others by the Nigerian Government (Human Rights Watch 1999). ${ }^{6}$

There is a growing consensus among individuals and organizations concerned with the promotion and protection of human rights that TNCs should be accountable for violations of international human rights law related to their business activities (Muchlinski 2001: 31-32; Ratner 2001: 446-448). This consensus is reflected in a growing academic, nongovernmental and intergovernmental literature that assesses the human rights impacts of corporate activity (UN 1995), and the legal and non-legal mechanisms by which these entities may be held responsible for violations of human rights (see, for example, Frey 1997; Clapham 2000; Forcese 2002; International Council on Human Rights Policy 2002).

Under international human rights law states have an obligation to respect and ensure respect for human rights within their territorial jurisdiction. Problems arise however, where TNCs operate in conflict zones or repressive regimes and are implicated in violations of human rights that are committed by a host state government or that the latter is unable or unwilling to prevent. Neither general international law nor international human rights law clearly impose direct legal obligations on TNCs to respect human rights (Frey 1997: 163; Joseph 1999: 175; McCorquodale 2002: 92-97). Nor does there appear to be an international legal obligation on the 'home' states of these business entities to ensure that the latter observe international

4. Other GNPOC members were the Sudanese state oil company Sudapet, China National Petroleum Company and Petronas Carigali.

5. Unocal and Total F.A., partners in another joint venture in Burma to build the Yadana pipeline have been accused of complicity in similar human rights violations including forced displacement, forced labour, sexual assault, extrajudicial murder and torture.

6. Shell continues to operate in the Niger Delta in its joint venture with the Nigerian government currently producing approximately one million barrels a day, approximately half of Nigerian oil production (Freeman 2004). BP is still active in Colombia. 
human rights standards in their extraterritorial activities (Brownlie 1983: 165; Joseph 1999: 180-181). ${ }^{7}$

The domestic legal mechanisms that are currently available to home state governments and private actors to challenge extraterritorial corporate conduct have not proven sufficient to ensure that TNCs respect human rights when operating outside of their home state jurisdictions. Some states, such as the U.K., are currently considering draft legislation that would address some aspects of extraterritorial corporate conduct (U.K. Parliament 2003). However, to date, no state has enacted specific legislation to regulate the extraterritorial activities of corporate nationals that may have a detrimental effect on the human rights of individuals in host states. In Canada, for example, there are no effective legal mechanisms in place to require the assessment of the human rights impact of proposed investment in host states, to prevent such activity where it is clear there will be a negative human rights impact or to monitor corporate conduct to ensure that Canadian investment abroad does not contribute to, or profit from, violations of human rights. Legal mechanisms including the foreign tax credit provisions of the Income Tax Act, Export Development policies and practices, the Area Control List under the Export and Import Permits Act, the Special Economic Measures Act and the Crimes Against Humanity and War Crimes Act which could be used by the government to compel or induce Canadian companies to improve their human rights conduct abroad are not sufficient on their own to require TNC compliance with international human rights and humanitarian law in their overseas business activities (CLAIHR 2000; Gagnon, Macklin and Simons 2003: 58-66). Nor does Canadian law provide sufficiently effective tools for private actors to exert market pressure on these entities, such as mandatory social and environmental corporate reporting, amended pension fund laws to allow for socially responsible investment criteria or whistleblower protection for individuals who report information of human rights violations related to overseas operations (Canadian Democracy and Corporate Accountability Commission 2002).

7. See also Crawford (2002: 91-121). Under the Draft Articles on State Responsibility of the International Law Commission, there is no apparent obligation incumbent on a home state to take steps to prevent the effects of the extraterritorial activities of corporate nationals. There appears to be an emerging consensus that TNCs are bound by fundamental norms of international law that prohibit, among other things abuses such as forced labour, slavery, genocide, torture and crimes against humanity (Kamminga and Zia-Zarifi 2000: 8). Companies that transgress these principles might be criminally prosecuted in any state under the principle of universal jurisdiction and officers and employees of corporations may be subject to prosecution as individuals in the International Criminal Court (ICC). However, the ICC does not currently have jurisdiction to prosecute corporations, and to date no companies have been criminally prosecuted in domestic courts for such abuses (Ramasastry 2002: 153-156). 
TNCs have been sued under tort laws in various jurisdictions for such violations. However, the effectiveness of these claims to deter corporations from complicity in human rights violations is questionable due to the cost, jurisdictional hurdles for the plaintiffs (Meeran 2003: 8) and evidentiary difficulties. Suits against Talisman, Shell, Unocal and other companies have been brought under the U.S. Alien Tort Claims Act for complicity in human rights abuses committed by security forces. Although some claims have moved beyond the jurisdictional phase, no contemporary case against a TNC brought under the ACTA has yet resulted in compensation to the victims of such abuses (Macklin 2003: 279). ${ }^{8}$

Public pressure to address this 'governance gap' has prompted action from governments, corporations and NGOs. In an era dominated by free market ideology, increasing liberalization, and thus hostility towards legally binding regulatory measures, the response has been to promote the development and implementation of voluntary self-regulatory regimes (Mayne 1999: 239). The number of voluntary codes has steadily increased along with the emergence of other voluntary self-regulatory practices such as social reporting and verification.

Critics of these voluntary measures argue that their effect in regulating extraterritorial corporate activity and in solving the related human rights issues has been inadequate (Toftoy 1998; International Council on Human Rights Policy 2002: 7). A recent study, that examined Talisman Energy's joint venture investment in Sudan, its complicity in human rights abuses committed by Sudanese government-supported security forces in the course of protecting the oil fields, and the company's voluntary self-regulation efforts, found that the self-regulatory measures taken by Talisman had failed to prevent the corporation's complicity in egregious violations of human rights, including forced displacement (Gagnon, Macklin and Simons 2003). Despite the growing evidence of the inadequacy of corporate voluntarism, governments and TNCs continue to promote voluntary self-regulation as the most suitable means to regulate the human rights conduct of these corporate entities.

This paper will review and assess the voluntary self-regulatory instruments and practices of Talisman Energy, Premier Oil, BP and Shell. It will also undertake an analysis of codes or policies developed by industry, inter-governmental organizations (IGOs) and multistakeholder initiatives that have been adopted or endorsed by one or more of these companies or

8. See Presbyterian Church of Sudan v. Talisman Energy Inc., Wiwa v. Royal Dutch Petroleum Co., and Doe v. Unocal Corp. The claim against Unocal has proceeded to the merits while the case against its consortium partner in Burma, Total was dismissed on jurisdictional grounds. 
which may be applicable to their conduct. Each of these companies has been active in a conflict zone and/or repressive regime. Each has been the target of vigourous criticism by human rights groups and other activists for the company's complicity in egregious violations of human rights, committed by security forces in the course of protecting oil installations. In response to these allegations, each has developed a voluntary code and/or policy and performance assessment and verification practices to address the human rights impact of their activities.

Voluntary self-regulation regimes should be distinguished from mandatory self-regulation regimes that are based on legally binding and enforceable obligations set within a legislative framework. The human rights provisions, as well as most provisions relating to social and environmental conduct of the codes and policies discussed in this paper, are not based on binding and enforceable legal obligations. The voluntary aspect of these regimes pertains both to the adoption of the code, policy or set of principles, as well as to compliance with the standards the instrument in question may contain. Thus, corporations are not legally required to adopt such instruments. Nor are these entities legally accountable for actions that may contravene the provisions of an adopted instrument.

Many of the instruments discussed deal with a variety of concerns related to extraterritorial business activity, including labour rights (which are often distinguished from human rights) environmental issues, bribery and corruption and consumer protection. While some of the analysis in this paper may be applicable to corporate voluntarism in relation to these wider concerns, the discussion will focus on the effectiveness of these instruments in addressing corporate complicity in some of the more egregious human rights violations that have been associated with business activity in conflict zones and repressive regimes. It will examine the content of the human rights provisions, the language in which they are drafted, the mechanisms for oversight, as well as current TNC practice under these voluntary regimes.

\section{CONTENT OF HUMAN RIGHTS PROVISIONS}

The human rights provisions of most voluntary codes or policies are often vaguely worded and may also be expressed in permissive language, thus watering down any sense of obligation. In addition, the content of human rights provisions varies substantially between instruments.

\section{Corporation-Developed Codes and Policies}

The majority of corporation-developed codes deal very minimally with the issue of human rights abuses (Avery 2000: 48). A recent study of 
North American corporation-developed codes of conduct found that while the largest Canadian corporations "like many of their U.S. counterparts, [were] beginning to consider human rights issues in their international practices", a majority of large Canadian companies active internationally did not "have codes containing reference to even the most basic human rights standards". The report came to similar conclusions regarding U.S. corporate codes relating to international activity and noted that the findings "replicate those identified with respect to domestic codes of conduct" of U.S. and Canadian companies (Forcese 1997: 43, 30).

A comparison of the voluntary codes and/or policies of BP, Shell, Talisman and Premier Oil is illustrative of the lack of consistency between, and the insufficient definition of, human rights commitments set out in corporate policy documents. Each corporate policy displays a slightly different level of commitment to respect human rights and none of the codes or policies makes a clear statement of obligation on the part of the company to be bound by international human rights standards.

From a review of public documents, BP's human rights policy appears to be the most comprehensive of the four companies. BP's policy on ethical conduct asserts the company's belief that the "promotion and protection of all human rights is a legitimate concern of business". The company asserts its respect for domestic law and notes that BP "supports" the principles set forth in the Universal Declaration of Human Rights (UDHR), the ILO Tripartite Declaration and the OECD Guidelines for Multinational Enterprises. It further states that it will not employ child or forced labour, and that it will evaluate the likely impact of its presence and activities before making major investments (BP 2002a). In another document prepared for employees, BP states: "It is the responsibility of States to defend the human rights of their population. As a company, we have a responsibility to contribute to the promotion of human rights and to consider the impact of our operations. We will ensure that we adhere to the principles of human rights within our operations and in those areas under our control" (BP 2000: 9) [emphasis added]. This document also sets out specific questions employees must consider in order to ensure that the company does not contribute to, or is not complicit in human rights violations.

Shell's Statement of General Business Principles declares that its responsibilities include the requirement "to observe the laws of the countries in which they operate, to express support for fundamental human rights in line with the legitimate role of business ..." (Shell 2002a: 5). This is not a clear statement of obligation to observe or be bound by international human rights standards and a "Management Primer" which discusses the role of business with respect to human rights also does not make a specific statement in this regard (Shell 2002b). Other statements on the company's 
website do appear to suggest that corporations are responsible for certain international human rights standards: "The Universal Declaration of Human Rights is aimed primarily at governments. Our challenge is to determine the specific responsibilities of Shell companies and provide managers with the necessary tools to meet their obligations" (Shell, "Our Approach to Human Rights"). In another report, Shell states that its "responsibilities to human rights" include employee rights, security, community rights, national rights and advocacy (Shell 2002c: 10-11).

Talisman's "Policy on Business Conduct" and its "Sudan Operating Principles", which together outline the company's commitment to human rights, are broadly worded and do not address specific human rights concerns that have been associated with Talisman's joint venture operations in Sudan. Among other things, the company states that it endorses the International Code of Ethics for Canadian Business (ICECB) and "has undertaken to use its best efforts to ensure that Talisman's operations reflect the principles embodied therein" (Talisman, "Policy on Business Conduct"). Under its Sudan Operating Principles the company commits "to addressing human rights concerns arising from Talisman and GNPOC operations" and undertakes to support "the principles of the Universal Declaration of Human Rights within Sudan" (Talisman, "Sudan Operating Principles"). Talisman is slightly more explicit in its most recent Corporate Social Responsibility (CSR) report. It states that under the ICECB, the company supports and promotes "the protection of human rights within [its] sphere of influence" and that it "will not be complicit in human rights abuses" (Talisman 2003: 8).

Premier Oil's human rights policy is similarly vague. It merely refers to the fundamental rights set out in the UDHR and the labour rights listed in "core" ILO Conventions. While the company does not state that it is bound by those rights, it does make a clear commitment to protect and promote these rights in its business operations and with its business and local community partners. It also states that the company will "use its legitimate influence to promote the protection of human rights outside [its] areas of operation" (Premier Oil 2002: 5). In addition, its "Corporate Social Responsibility Policy" states that the company will, among other things, assess its human rights impact prior to commencement of, or withdrawal from, a project and conduct its activities having regard to the findings of such assessments (Premier Oil 2002: 4).

\section{Other Voluntary Codes and Principles Applicable to Extraterritorial Corporate Activity}

The fact that TNCs may also sign on to, or endorse, voluntary codes or principles developed by industry, IGOs, NGOs or multistakeholder groups 
does not necessarily improve the standards of accountability. ${ }^{9}$ The deficiencies of corporation-developed codes and policies are also reflected in many of these other codes, guidelines and benchmarks.

In 1976, as part of its Declaration on International Investment and Multinational Enterprises and related decisions of its Council, the Organisation for Economic Co-operation and Development (OECD) released the OECD Guidelines for Multinational Enterprises (OECD Guidelines) aimed at providing "voluntary principles and standards for responsible business conduct" (OECD 2000a: 2). The Guidelines cover a range of issues including labour relations, environmental impact, bribery, consumer protection and competition. They were most recently reviewed and updated in June 2000. The changes included, among other things, the addition of a general provision on human rights and provisions relating to child and forced labour (OECD 2000a: 2, note 3). The Guidelines are drafted in permissive language and the content of the new general human rights provision-distinguished from the labour rights provisions-is illdefined. TNCs are merely encouraged to "[r]espect human rights of those affected by their activities consistent with the host government's international obligations and commitments" (OECD 2000a: 11). ${ }^{10}$ Additionally, international law appears to play a secondary role in the Guidelines. The host state government's right to "prescribe the conditions" under which TNCs within their jurisdiction must operate is subject to international law (OECD 2000a: 9), but the Guidelines make it clear that TNCs are subject first and foremost to local laws (OECD 2000b: 12).

A particularly important initiative in terms of addressing human rights concerns related to business activity in zones of conflict and repressive

9. Talisman has signed on to the ICECB. Both BP and Shell have endorsed the Voluntary Principles on Security and Human Rights and appear to have taken steps to implement these guidelines. BP, Shell and Premier Oil have expressed support for the OECD Guidelines and signed on to the Global Compact.

10. A subsequent document released by the OECD in October, 2001 purports to clarify these obligations, noting that, while human rights are primarily the responsibility of governments, it is acknowledged that corporations do play a role when corporate conduct "intersects" with human rights. In these circumstances, TNCs are "encouraged" to respect the human rights not only of employees but also the human rights of other individuals who are affected by the corporations activities. Such respect must be "consistent with the host government's international obligations and commitments". The document further notes that in this regard, the UDHR and "other human rights obligations" of governments concerned are of particular relevance. Apart from the reference to the host states' international obligations and the UDHR there is no further clarification as to what "respecting human rights" means and how a company can ensure that it is complying with these obligations. Nor do the Guidelines deal with the problem of the human rights issues raised where national military or private security forces are engaged by corporations (or consortiums of which corporations are members) to protect corporate facilities in the host state (OECD 2000b: 12). 
regimes is the Voluntary Principles on Security and Human Rights (Voluntary Principles). These principles were the result of an eleven-month dialogue between the U.K. Foreign and Commonwealth Office, the U.S. Department of State, major TNCs in the extractive industry, including BP and Shell, and key international human rights NGOs, as well as business and union groups. ${ }^{11}$ The Voluntary Principles provide specific guidelines for the protection of corporate assets by public and private security while ensuring respect for human rights. While there are innovative features in this code, these principles are couched in permissive language. Like the OECD Guidelines, respect for domestic law of the host state takes precedence over any international law standards. Companies signing on to the Voluntary Principles "recognize a commitment" to obey the laws of the host state, but are only required to be "mindful of the highest applicable international standards" and to "promote" rather than ensure "the observance of applicable international law enforcement principles" (U.S. Department of State 2001).

The idea for the Global Compact (Compact) was put forward by the UN Secretary-General, Kofi Annan at the 1999 World Economic Forum in Davos, Switzerland. Annan challenged business leaders to address social and environmental concerns related to corporate activity in the global economy by adopting a set of "shared values and principles" that would "give a human face to the global market" (UN 1999). The Compact sets out nine principles relating to human rights, labour rights and environmental standards, which, like those of the instruments discussed above, are drafted in permissive language. The human rights provisions compare favourably in terms of human rights content against the OECD Guidelines. However, they are less detailed on the employment and conduct of security forces than the Voluntary Principles. Businesses adhering to the Compact are requested in Principles 1 and 2 to "support and respect the protection of internationally proclaimed human rights within their sphere of influence; and ... make sure their own corporations are not complicit in human rights abuses". The explanation of Principle 1 sets out business reasons to address human rights issues. Among other things, it also provides examples of "how companies can guarantee human rights through their daily activities", including "by ensuring that they do not use directly or indirectly forced

11. The Voluntary Principles are supported by the U.S. and U.K. governments, Chevron, Texaco, Freeport McMoran, Conoco, Shell, BP, Rio Tinto, Amnesty International, Human Rights Watch, International Alert, Lawyers Committee for Human Rights, Fund for Peace, Council in Economic Priorities, Business for Social Responsibility, The Prince of Wales Business Leaders Forum, and the International Federation of Chemical, Energy, Mine and General Workers' Unions (Statement by the Governments of the United States of America and United Kingdom 2000). Norway and the Netherlands have now also expressed support for the principles (BP 2003a: 18). 
labour or child labour", "by preventing the forcible displacement of individuals, groups or communities", and by ensuring that security providers respect the international guidelines on the use of force. The elaboration of Principle 2 includes a definition of three types of complicity: direct, beneficial and silent. The issue of forced displacement is mentioned in an example of direct complicity. It also recommends that companies respect international guidelines on the use of force, that corporations providing financial or material support to security forces "establish clear safeguards to ensure that these are not then used to violate human rights", and that companies ensure that any agreement with security forces clearly states that the corporation "will not condone violations of international human rights laws" (UN Global Compact Website). ${ }^{12}$

The Global Sullivan Principles of Social Responsibility (Global Sullivan Principles) and the International Code of Ethics for Canadian Business (ICECB) are the weakest of the instruments surveyed. The Global Sullivan Principles are the successor to the Sullivan Principles developed by Rev. Leon Sullivan in 1976 and adopted by 200 U.S. corporations operating in South Africa under the apartheid regime (Cassel 1996, 1970). Under those principles, corporations agreed, among other things, not to practice racial segregation in the workplace, to give equal pay for equal work and use their influence to end apartheid (Danailov 1998: 47). The Global Sullivan Principles which were also developed by Rev. Sullivan in consultation with TNCs and business groups and launched in 1999, are more broadly applicable and include principles on universal human rights, specific labour rights, property interests and bribery. ${ }^{13}$ The ICECB was jointly developed in 1997 by the Human Rights Research and Education Centre at the University of Ottawa and a group of Canadian TNCs, and addresses concerns related to the environment, human rights, bribery and corruption, and labour.

The provisions of both of these codes are broad, aspirational and drafted in permissive language. They provide little effective guidance for TNCs. The ICECB, for example, is divided into three sections, "Beliefs", "Values" and "Principles". It underscores the sovereign right of states to "conduct their own government and legal affairs" while noting that states should comply with their international obligations including those relating

12. As of January 15, 2004, 1195 companies had endorsed the Global Compact, including 50 U.S. companies, 28 U.K. companies, 10 Japanese companies and 10 Canadian companies (UN Global Compact Website).

13. As of October 9, 2002, 189 businesses (including TNCs), 16 business associations, 16 U.S. municipal governments, 54 non-profit organizations and 8 higher education institutions or associations among others had endorsed the Global Sullivan Principles (Global Sullivan Principles Website). 
to human rights and social justice. Among the values listed are human rights and social justice, along with "[w]ealth maximization for all stakeholders" and "[g]ood relationships with all stakeholders". Corporations that sign on to the code agree that they will "support and promote the protection of international human rights" within their "sphere of influence" and that they will "not be complicit in human rights abuses". While the inclusion of the issue of complicity is important, there is no further clarification of the meaning of "complicity". Furthermore, there are no benchmarks against which corporations could measure activity that supports or promotes the protection of human rights. The code aims to serve as a basis for "the development of operational codes and practices that are consistent with the vision, beliefs, values and principles" by signatory companies (Human Rights Research and Education Centre Website). ${ }^{14}$

Only the UN-developed Norms on the Responsibilities of Transnational Corporations and Other Business Enterprises with Regard to Human Rights (UN Norms) provide a comprehensive set of principles that, in addition to labour, environmental and consumer protection issues, sufficiently addresses potential human rights concerns associated with the overseas activities of TNCs in conflict zones and repressive regimes. These norms are the product of a four-year drafting and multistakeholder consultation exercise by the Working Group on Transnational Corporations (spearheaded by Working Group member, Professor David Weissbrodt) within the UN SubCommission on Prevention of Discrimination and Protection of Minorities (now the Sub-Commission on the Protection and Promotion of Human Rights). The Working Group was established in 1999 "to examine the working methods and activities of transnational corporations" (Weissbrodt 2000: 130), and a decision was made to "consider developing a code of conduct for business enterprises based on human rights standards" (UN 2002a: para. 1). A separate document containing the Norms with Commentary provides an "interpretation and elaboration of the standards contained in the Norms" (UN 2003b).

In a resolution of August 13, 2003, the Sub-Commission unanimously approved the Norms and submitted them to the UN Commission on Human Rights for consideration and adoption (UN 2003c: para. 2). However, garnering support for the Norms both within and outside the UN is likely to remain a challenge. Several powerful business lobby groups have vigourously criticized the principles for their "binding and legalistic approach" (UN 2003d), and argue that "any shift toward mandatory compliance would violate accepted international standards" (Boyd 2003). While still currently a voluntary instrument, it is the only set of principles that is drafted in

14. It is not clear how many companies have adopted the ICECB. 
mandatory language, and that creates a direct and unambiguous obligation on the part of TNCs to respect international human rights standards. ${ }^{15}$

Under the UN Norms, TNCs are required "to promote, secure the fulfilment of, respect, ensure respect of, and protect human rights recognized in international as well as national law, including the rights and interests of indigenous peoples and other vulnerable groups" within their sphere of activity and influence (UN 2003a: Article 1). These principles also provide a far-reaching definition of TNCs (Articles 20 and 21) and include a prohibition on the commission of, complicity in or benefiting from violations of international humanitarian law and fundamental human rights (Article 3 ). The principles contain rules and provisions on the hiring and conduct of public and private security forces (Article 4). They also oblige TNCs "to respect the principle of free, prior and informed consent of the indigenous peoples and communities," and prohibit both forced displacement of such communities and the deprivation of their means of subsistence (UN 2003b: Article 10, para. c). In addition, the Norms recommend that states establish "the necessary legal and administrative framework for ensuring that the Norms and other relevant national and international laws are implemented" by TNCs (Article 17). It is not clear from the Commentary, however, whether this provision was meant to impose an obligation, not just on host states to regulate TNC activity within their territory, but also on home states to ensure that TNCs implement the Norms in their extraterritorial operations (UN 2003b: Article 17, para. a).

\section{CODES PROVIDING FOR OVERSIGHT OF COMPLIANCE}

In addition to clearly defined, mandatorily expressed human rights obligations, a credible process to oversee corporate compliance with such obligations is crucial to the effectiveness of voluntary self-regulation. Current voluntary initiatives are deficient in this regard. Not only are the performance standards inadequate in most cases, many of these instruments lack any credible compliance mechanisms at all. There are a number of ways in which such oversight can be accomplished, of which independent monitoring is the most important. To be effective, such monitoring must, among other things be transparent and be conducted by a third party who is independent of the host government and business entity under review, who is knowledgeable about the issues in question, and the social, cultural and political context in which the business is operating, and who is trusted by the local workers or affected population (see Bernard 1997: 10-12).

15. To date only Algeria, Switzerland, Sweden, two large business groups and seven companies (ABB, Barclays, MTV Europe, National Grid Transco, Novartis, Novo Nordisk and The Body Shop International), have endorsed the Norms (Weissbrodt 2003; Maitland 2003). 
Corporation-developed codes typically do not provide for independent monitoring (see Forcese 1997: 43, 30), and this is true of the four corporate codes and policies reviewed above. Among the industry, IGO and multistakeholder instruments surveyed, only the UN Norms specifically provide for a form of transparent, independent monitoring of a TNC's application of the Norms "by United Nations, other international and national mechanisms already in existence or yet to be created". The term "monitoring" is not defined, but the Commentary suggests that it includes both monitoring of implementation of the norms by TNCs themselves (which would not qualify as "independent") and ad hoc monitoring of compliance by a variety of bodies. The Commentary further recommends, among other things, the establishment of a body under the Commission on Human Rights "to receive information and take effective action when enterprises fail to comply with the Norms". It also suggests that a forum be established under the Sub-Commission on the Promotion and Protection of Human Rights for receiving, and allowing corporate response to, complaints of non-compliance (UN 2003b: Article 16, para. b).

The OECD Guidelines do not provide for independent monitoring of corporate conduct. However, they do establish an intergovernmental process for dealing with TNC compliance with the Guidelines. Participating states are required to set up National Contact Points (NCPs) (OECD 2001a: 3). NCPs can consist of a single government official or a government office that is headed by a government official. They may also be structured as an inter-departmental government group and may include representatives from the private sector, unions and other members of civil society (OECD 2000a: 27). Among other things, NCPs are expected to, promote and raise awareness of the guidelines, assist TNCs with implementation, and deal in a consultative, non-adversarial manner with TNCs where problems of non-compliance of the Guidelines arise.

There are a number of problems with this compliance mechanism in terms of effectively monitoring corporate conduct. First, TNC participation in such consultations is voluntary. NCPs are permitted to keep information about such consultations confidential (OECD 2000a: 27-28) and have been criticized for their reluctance "to alienate companies by aggressively publicising clear cases of wrongdoing" (Habbard 2001: 102). Second, only 36 states currently adhere to the guidelines. These include the 30 members of the OECD ${ }^{16}$ and six non-OECD members. ${ }^{17}$ Efforts to bring new members

16. The current OEDC members are Australia, Austria, Belgium, Canada, Czech Republic, Denmark, Finland, France, Germany, Greece, Hungary, Iceland, Ireland, Italy, Japan, Korea, Luxembourg, Mexico, Netherlands, New Zealand, Norway, Poland, Portugal, Slovak Republic, Spain, Sweden, Switzerland, Turkey, United Kingdom, United States.

17. Non-OECD members that have agreed to adhere to the Guidelines are Argentina, Brazil and Chile, Estonia, Lithuania and Slovenia. 
on board have not been very successful (OECD 2000c: 67, 70-72). Such state support is substantial compared with the Voluntary Principles, for example. However, most adhering states are developed countries with fairly effective domestic laws to regulate TNC activity within their jurisdiction. Thus, in terms of overseeing the conduct of TNCs in conflict zones or repressive regimes, the process is limited. Although it is possible to raise the issue of non-compliance with a home-state NCP where concerns arise about a TNC's behaviour in a non-adhering state, any investigation by such NCP might be hampered by a non-cooperative host state. This is particularly true if the latter is implicated in the complaint. Third, the structure and activity level of NCPs and the discretion for implementation of these objectives and duties are left largely to individual governments and some have argued that "[t]oo many NCPs are still dormant and/or fail to consult with trade unions and other interested parties" (OECD 2001b: 40).

Fourth, there is a process that allows members of the public, NGOs and governments to raise issues about extraterritorial corporate conduct (OECD 2000a: 27), and over 40 cases have been initiated since the 2000 review. However, among other problems, such as the lack of a central registry of cases, there is inconsistency among NCPs "about informing parties of progress in handling cases; providing information to third parties; making public the fact that a case has been filed; issuing statements while a matter is still under consideration; [and] making public reasons for not proceeding with consideration of a case" (OECD Watch 2003: 6).

There is also no specific timeframe for dealing with complaints, which has allowed some NCPs to drag their feet. (Feeney 2002: 2). A case was filed in November 2002 by the Canadian Labour Congress requesting the Canadian NCP to investigate Ivanhoe Mines for complicity in forced labour and environmental damage related to its mining activities in Burma is only now beginning to move forward (Government of Canada 2003). Notably, the UN Panel of Experts Report on the Illegal Exploitation of Natural Resources and Forms of Wealth of the Democratic Republic of the Congo, which was released in October 2002 named 85 TNCs, many from OECD countries, for violations of the Guidelines (OECD Watch 2003: Appendix). A final report of the panel, released in October 2003 was criticized for its reduced mandate and lack of transparency and rigour regarding the apparent exoneration of some companies. Despite the release of the two reports and their inconsistencies, critics have noted that "almost no action has been taken by National Contact Points" to formally investigate the panel's allegations (Feeney et al. 2003).

Some cases, which have been resolved, have brought about changes in corporate conduct, while others have not. For example, an issue raised with the Canadian NCP regarding First Quantum Mining (Canada) and 
two other companies in Zambia over the resettlement of tenant communities, resulted in the companies withdrawing their threat of eviction and agreeing to set aside land for the local residents (OECD Watch 2003: Appendix). On the other hand, the outcome of a case raised with the French NCP about corporate complicity in forced labour in Burma, was a mere recommendation to companies operating in that country "to do everything possible in order to avoid direct or indirect recourse to forced labour" (Feeney 2002: 5).

Finally, there is no enforcement of decisions and, as noted above, the company's identity is often not disclosed. It has been argued that with no public scrutiny, the "procedure has little immediate impact on the behaviour of specific companies" (International Council on Human Rights Policy 2002: 101-102).

\section{REPORTING ON HUMAN RIGHTS PERFORMANCE}

Another compliance mechanism associated with voluntary self-regulation is the emerging practice among TNCs adhering to such voluntary codes, of voluntarily producing a self-evaluation of their social performance.

\section{Provisions Requiring Reporting on Human Rights Performance}

For the most part, codes and policies do not provide for such reporting. Of the corporate codes reviewed, only Premier Oil's policy clearly commits to "regular social audits and assessments of compliance" of human rights performance (Premier Oil 2002: 4). ${ }^{18}$ Some of the international instruments discussed above have reporting requirements. As with the human rights provisions, the reporting "obligations" vary in stringency as between instruments.

The OECD Guidelines, for example, set out specific information that should be disclosed in company reports, including information with respect to "[m]aterial foreseeable risk factors", "[m]aterial issues regarding employees and other stakeholders". However, there is no clarification as to what these factors and issues should include. The voluntary disclosure requirements are also subject to an exception that allows corporations in formulating their disclosure policies to take into account "costs, business confidentiality and other competitive concerns" (OECD 2000a: 12).

Under the Global Compact, adhering corporations are merely "expected to issue a 'Communication on Progress' in their annual reports and/or other

18. Both BP and Shell do explain their reporting practices in some detail on their websites. Shell has recently committed to reporting on so-called "hot-spots" in its upcoming 2003 report (Shell 2003: 11). 
prominent public reports" (UN Global Compact 2003: 9) ${ }^{19}$ A positive development with regard to reporting under the Compact was the joint release with the Global Reporting Initiative (GRI) of a document specifying how GRI indicators could be used in such reports (GRI 2003).

The reporting provisions of the UN Draft Norms are more rigorous than those discussed above. Article 15 requires TNCs to periodically report on their measures to implement the Norms. TNCs are required to be transparent in their activities and to this end provide "timely, relevant, regular and reliable information regarding their activities, structure, financial situation and performance" (UN 2003b: Article 15, para. d). Article 16 imposes an obligation on TNCs to conduct periodic self-assessments of their compliance with the Norms that take into account input from stakeholders and consultations with indigenous peoples and communities. The self-assessment must be made available to stakeholders "to the same extent as the annual report" (UN 2003b: Article 16, para. g). Where such assessments show inadequate compliance, TNCs are obliged to include plans to redress or make reparations regarding their negative impact (UN 2003b: Article 16, para. h). The background material suggests that self-assessments could be conducted by the company itself or by an independent consultant and the results could be made public so as to increase the transparency and legitimacy of the process. However, it also notes that "the expectation of publicity may discourage adequate disclosure" and suggests that if assessment reports are going to be publicly released, then independent third parties such as expert NGOs, trade unions, labour associations or states may be better candidates to conduct the assessment (UN 2002b: 13).

\section{Voluntary Reporting Standards}

There are currently no universally accepted reporting standards for social or human rights performance reporting. The Global Reporting Initiative's 2002 Sustainability Guidelines (the "GRI Guidelines"), however, is a noteworthy attempt to fill this gap. These voluntary Guidelines were produced through a multistakeholder consultation process between NGOs, IGOs and the private sector. Originally spearheaded by the U.S. Coalition for Environmentally Responsible Economies (CERES), the GRI was cofounded by CERES and the United Nations Environment Programme (UNEP) in 1997 with the goal of producing universal standards for reporting on environmental, social and economic impact of business activity (Waddell 2002: 5-7; UNEP Website). It is a work in progress and the long-term aim of the initiative is to create greater harmonization of reporting approaches

19. The Global Sullivan Principles have similarly weak reporting requirements (Global Sullivan Principles Website). 
that will ultimately become "generally accepted sustainability accounting principles" (GRI 2002: 5). The latest version of the Guidelines, released in August 2002, has been substantially revised since the release of the first set of guidelines in 2000. The GRI also states that it is developing sector supplements and issue supplements that can be used with the guidelines as well as technical protocols on indicator measurement (GRI 2002: 10).

While the Guidelines do address many of the fundamental concerns regarding social reporting, as currently drafted they also raise significant concerns. In the first place, GRI reports are designed to be centrally generated and the Guidelines do not provide site-specific indicators that address the particular operating environment of a company. For full reporting on human rights issues the GRI indicators will have to be supplemented (Macfarlane 2002: 22).

Second, while the indicators for human rights reporting have been substantially enhanced from the earlier drafts of the guidelines, the division of indicators into core and additional indicators means that a reporting company could produce a report "in accordance" with the GRI Guidelines that does not include indicators that are of importance to certain stakeholders (although to do so would technically violate the principle of inclusiveness).$^{20}$ Moreover, current human rights indicators still do not address some very fundamental issues related to business activity in conflict zones and

20. Core indicators are defined as those "relevant to most reporting organizations; and of interest to most stakeholders" as determined through an extensive multi-stakeholder consultative process. Additional indicators are those indicators that may represent best practice but are used by few reporting organizations, that provide information that may be significant to stakeholders who are important to the reporting organization, and that are "deemed worthy of further testing for possible consideration as future core indicators". However, although the GRI encourages the inclusion of indicators derived from consultation with stakeholders, as mentioned above, only core indicators are required to be included in a report for it to be considered "in accordance" with the Guidelines (GRI 2002: 12-13). At present, the core performance indicators for human rights require reporting on the existence and a description of policies, guidelines, and procedures, including monitoring systems/mechanisms and the results of monitoring with respect to: all aspects of human rights relevant to the reporter's operations (HR1); evidence of consideration of human rights impacts as part of investment procurement and decisionmaking (HR2); human rights performance of the reporting organization's supply chain and contractors (HR3); the exclusion of discrimination (HR4); the protection of freedom of association (HR5); child labour as defined by the ILO Convention 138 (HR6); the prevention of forced labour (HR7); impacts on communities affected by the reporting organization's activities (SO1). Other equally important issues are relegated to the category of additional indicators. These include employee training on corporate human rights policies and indicators regarding employee discipline and grievance practices, human rights training for security personnel, existence of jointly managed community grievance mechanisms, management principles with respect to indigenous peoples and local redistribution of a share of operating revenues (GRI 2002: 53-55). 
repressive regimes. There are no indicators for reporting specifically on an organization's relationship with public and/or private security forces, consultations with the host state with respect to public security forces, equipment supplied for security force use, dual use equipment and the monitoring of such use, local population displacement and compensation practices, and other grievous human rights abuses or violations of international humanitarian law.

\section{The Practice of Transnational Corporations}

Each of the corporations under review has voluntarily produced reports that deal to varying extents with their social or human rights performance. The current reporting practice among TNCs, that appears to be typified by these companies, raises serious concern about the adequacy of the report content and the credibility of the self-assessment and reporting framework used. Few companies appear to have developed transparent and credible social accounting frameworks, with procedures and methodologies that ensure the accuracy and completeness of human rights related data collection or that reveals, among other things, how decisions were made on the selection of stakeholders for consultation, or the selection of information to be included in the report.

Reporting formats and practices differ from corporation to corporation. Both Shell and BP have produced a review of overall social and environmental corporate activity. Shell notes that its 2001 report is "produced within the broad framework of the GRI guidelines" (Shell 2002c: 48), while BP produced a separate GRI report with links to examples on its website. BP also produces more in-depth location reports of selected operations. Talisman's 2002 report claims to have been "developed in the spirit" of the GRI guidelines (Talisman 2003: 4), while Premier Oil states that its 2002 report is "written in accordance with the reporting framework" of the guidelines (Premier Oil 2003: 9). Premier Oil's and Talisman's 2002 reports are more broadly focused than their previous reports which reviewed performance associated with particular operations that have come under public scrutiny. Although the reports examined in this section are not all GRI reports, the Guidelines are used here as a standard reflective of best practice to assess the reporting practices of these companies.

\section{Transparency}

The GRI Guidelines require reporting to be informed by the principles of transparency, inclusiveness, auditability, completeness, relevance, sustainability context, accuracy, neutrality, comparability, clarity and timeliness. The Guidelines state that such principles are "integral to [the 
GRI's] reporting framework" and considered to be "equal in weight" to the information elements contained in the "Report Content" section of the guidelines (GRI 2002: 22-31).

The principle of transparency is considered an "overarching principle" and requires that the reporting organization fully and formally disclose the processes, procedures and assumptions underlying the preparation of the report. These would include, for example, the process by which stakeholders were consulted and how these consultations informed the boundaries, scope and content of the report, as well as disclosure of "data collection methods and related internal auditing, and scientific assumptions underlying the presentation of information" (GRI 2002: 24).

Of the reports reviewed, only Premier Oil's 2001 Report sets out the methodology of the social accounting process. It gives an explanation of which stakeholders were included and why, along with a fairly detailed description of the procedures and processes developed and used for the social accounting which resulted in the Report (Premier Oil 2002: $11-17) .^{21}$

\section{Corporate Impact within Broader Human Rights Context}

Another key concern with human rights performance reports is that they do not appear to adequately address fundamental human rights issues raised by a company's activity in a particular location or the broader human rights context of the reporting TNC's operations.

The GRI Guidelines require reporting organizations, to place their sustainability performance within the broader context of the effects of such performance on the, local, regional and global economy, environment and social sphere, but only "where such context adds significant meaning to the reported information" (GRI 2002: 27-28).

Until March 2003, Talisman was operating in a joint venture in Sudan that was implicated in gross violations of human rights, including forced displacement. Talisman's 2000 CSR Report does not mention the fact of forced displacement. Moreover, the 2001 Report distinguishes between "oil related displacement" and "conflict, famine and drought related displacement" (Talisman 2002: 16). This gives the false impression that the latter is unrelated to oil exploration and development and therefore not a responsibility of the company. Neither report addresses or raises the issue of the contribution of oil exploration and extraction to an exacerbation of the conflict. Nor do the reports discuss in detail whether revenues from

21. Premier Oil's latest report is much less rigourous in this respect (Premier Oil 2003: 12). 
oil extraction have contributed to the Government of Sudan's ability to wage war against its own people, despite evidence put forward in credible reports supporting these conclusions (Amnesty International 2000; Gagnon and Ryle 2001; Gagnon, Macklin and Simons 2003; Human Rights Watch 2003b). ${ }^{22}$

Similarly, neither of Premier Oil's reports question in any way the appropriateness of its investment in Myanmar and its relationship with a brutally repressive government with a record of grave human rights violations such as forced labour and forced displacement associated with extractive industry operations. Nor does it even mention the issue of political repression in Myanmar, which as the verifier for the 2001 report notes would "unavoidably" have restricted the stakeholder consultation conducted on behalf of the company (Premier Oil 2002: 70). ${ }^{23}$

Even among those companies that are considered forerunners in the area of corporate social responsibility, reports do not always give sufficient information about the context of a human rights situation or steps taken by these corporations with respect to their human rights performance. For example, Shell's 2002 Report, like its previous reports, sets out its policy on security and human rights and the number of security incidents that have occurred in its various operations. The report states that " $[\mathrm{t}]$ hirteen countries reported significant security incidents during 2002, including war and civil unrest and violent crimes" and notes that in two countries armed security contractors were not operating in compliance with Shell's security guidelines. However, apart from a brief reference to attacks and hostage takings in Nigeria, there is no further elaboration of the security incidents cited, the political context in which they took place or how the company dealt with them. The only information that has been verified by KPMG and Pricewaterhouse Coopers ( $\mathrm{PwC})$ is the data on the number of countries in which armed personnel are used and the types of armed security personnel employed (Shell 2003: 33, 47).

\section{Neutrality of Reported Information}

Under the GRI Guidelines, the reporting principle of neutrality requires that sustainability reports "avoid bias in selection and presentation of

22. Although two of these reports were released after Talisman produced its CSR reports for 2000 and 2001, the evidence put forward in these latter studies corroborate the evidence set out in the Amnesty International and Gagnon and Ryle reports on these issues. Talisman was clearly aware of these issues as demonstrated by its brief treatment of them in the 2001 CSR report.

23. Premier Oil announced that it would be withdrawing from Myanmar in September 2002 (Premier Oil 2003: 72). 
information" and "strive to provide a balanced account of the reporting organisation's performance." The report should be a "fair and factual presentation" of the company's performance. Thus, a report should not consist of "selections, omissions, or presentation formats that are intended to influence a decision or judgment by the user" (GRI 2002: 29). For example, graphics used in a report should not "inadvertently lead readers to incorrect interpretations of data and results" (GRI 2002: 34).

There is a clear tendency in all the reports examined to put a positive spin on corporate performance and progress, notwithstanding the sporadic disclosure of corporate weaknesses or problems. In all three of the Talisman reports and in the Premier Oil 2001 Report, for example, quotes and/or pictures are strategically placed or selected in order to give support to claims made or to make positive impressions. Indeed, the Premier Oil verifier for the 2001 report remarks that "the exclusively positive nature of the enlarged and highlighted comments accompanying the report's photographs exhibit an explicit selection bias (Premier Oil 2002: 71).

\section{VERIFICATION}

As with social reporting, "verification" of social reports or social accounting frameworks is an evolving corporate practice. The term verification is often used interchangeably with the monitoring of corporate compliance with codes. However, for the purposes of this paper the term "verification" refers to an auditing process of social or human performance reports and is distinguished from monitoring. A leading academic in the area of verification or social auditing processes maintains that verification of social performance should include more than verifying the accuracy of data and claims made by the reporting company. It should also include an evaluation of the accounting framework and whether the appropriate mechanisms and methodologies were used in producing the information and the report (Macfarlane 2002: 1-2).

\section{Provisions Requiring Verification of Reports}

Because reports are voluntary self-assessments of a company's human rights performance, appropriately conducted independent verification of such reports could help to enhance their credibility. Again, few of the policies or codes examined require verification of the social accounting process. Only Premier Oil's policy specifically commits to verification of its reporting process (Premier Oil 2002: 4). The UN Norms provide for mandatory periodic monitoring and verification (Article 16). There is no further definition of verification, although an earlier draft of the Norms 
included the more specific requirement that reports on compliance be periodically verified with input from stakeholders (UN 2002c: Article 19). In the most recent introduction to the Norms, the drafters appear to take a broad view of verification as an ad hoc non-formalized process that can be accomplished both through dissemination of a social performance report, or a social audit process (UN 2002b: 13-14).

\section{Voluntary Verification Standards}

There are currently no accepted universal standards for verification or social auditing of human performance reports although there are private initiatives that are developing voluntary standards in this area. The GRI provides draft guidelines for non-financial audit processes. Independent verification, however, is not required for a report to be considered prepared "in accordance" with the Guidelines.

Verification guidelines have also been developed by a number of other initiatives. Social Accountability International (SAI) established in 1997 (under a different name) developed both a code of workplace standards and a system for verifying factory compliance with the code, known as SA8000. The verification system was developed from auditing techniques used by the International Standards Organization for verifying quality control (SAI Website). A more broadly focused verification standard has been generated by The Institute of Social and Ethical Accountability (AccountAbility), a non-profit organization established in 1996 by a group including the New Economics Foundation and the current AccountAbility Chief Executive, Simon Zadek, with the aim of "promoting accountability for sustainable development". The organization has a broad multistakeholder membership of "businesses, NGOs, service providers and researchers" representing 20 countries. According to AccountAbility, AA1000 Assurance Standard (AA1000 Standard), which was launched in 2003, was developed through "an extensive consultation process" (AccountAbility Website), although it is not clear who participated in such consultation. The standard, which can be used to audit or verify social, environmental and financial reports, appears to be gaining support in the business community. ${ }^{24}$

\section{The Practice of Transnational Corporations}

While some TNCs have engaged NGOs or academics to verify social accounting reports and processes, most appear to hire large private consulting/auditing firms to verify social performance reports. However, the

24. Premier Oil's verifier used the guidelines for the 2001 report and Ernst \& Young make reference to them in their assurance statement in BP's 2002 report. 
credibility of these "audit" type processes conducted by private consulting/ auditing firms is itself questionable, particularly in the wake of the Enron and WorldCom scandals.

\section{Mandate of Verification Report and Process}

With no universal verification standards or binding requirements, mandates for verification of social reports are determined by the reporting company and differ considerably in scope. This means that fundamental human rights issues will not be addressed except at the discretion of the reporting TNC and are unlikely to be raised by verifiers in a report that is publicly released. In the reports reviewed, human rights issues, if they are addressed at all, are only briefly mentioned.

The AA1000 Standard deals with this concern by requiring verifiers to assess whether the content of the social performance report is inclusive and thus satisfies the principles of materiality, completeness and responsiveness in terms of stakeholder concerns and decision-making (AA 2003: 12-19).

The mandate for PwC's verification of the Talisman CSR Reports was very narrow. In the 2001 Report, for example, PwC states that it had been requested "to audit and review certain statements and data" in the Report "relating to ... the policies and processes within Talisman and, where covered by the framework, within GNPOC with regard to the Sudan operations" and to conduct stakeholder consultation. PwC's verification statement does not discuss or critique Talisman's reporting methodology but merely notes whether or not the contents of the report "are supported by appropriate underlying evidence at Head Office level and local operations level" (Talisman 2002: 7). Nor is there an explanation of what constitutes "appropriate underlying evidence". For the 2002 Report, PwC's verification mandate was reduced to a review of certain assertions made in the Report to ensure they were supported by "appropriate underlying evidence" based on information supplied by Talisman (Talisman 2003: 6). PwC makes no substantive comments in its verification statements on human rights issues related to Talisman's investment in Sudan. It merely states that information set out in the report that has been verified is marked with a check. Comments from stakeholders that $\mathrm{PwC}$ selected for inclusion are interspersed throughout the CSR report and marked with another symbol. PwC placed check marks beside Talisman's paragraphs on "oil related displacement" and "conflict, famine and draught related displacement" with no further comment on the issue (Talisman 2002: 16).

Ernst \& Young, in verifying BP's Environmental and Social Review does not conduct stakeholder consultations at particular sites to determine whether the location issues have been adequately assessed. Rather, it verifies 
the business processes that underpin the issues covered in the report in order to substantiate its contents. The verifier visits a sample of sites each year to review the local business processes that cover the issues in the report and the processes for gathering relevant performance data. This involves reviewing local processes for identifying the appropriate focus of social and environmental activities, reviewing and tracking progress and reporting performance internally and externally (Johnston 2002: 13). Another company and certain consultants conduct stakeholder consultation. In some of the location reports $\mathrm{BP}$ has set out a one-page description of the consultation process (BP 2003b) and further information on stakeholder engagement is set out on the website. However, although BP does claim that its stakeholder views will be independently verified, the consultation processes and methodologies do not appear to have been publicly evaluated or the results of such evaluation verified..$^{25}$ The only human rights issue raised by Ernst \& Young in their verification report of BP's Environmental and Social Review 2002 relates to BP's implementation of the Voluntary Principles on Security and Human Rights. The verifiers briefly note that they expected more progress in this regard and that more work needs to be done in relation to operations in Angola and Azerbaijan (BP 2003a: 18, 31).

Premier Oil's pilot social accounting and verification project for the 2001 Report involved a much more comprehensive auditing of the social accounting process based on the AA1000 Standard than that of the private consulting/auditing firms. The verification mandate was quite broad and included verification both, of the design and conduct of the review process, and of the competence of the persons who designed and conducted the process (Premier Oil 2002: 63). The verifier's review and critique of the methodologies and processes used to generate the report exposed the flaws in the social accounting framework and the report, injecting a large amount of transparency and credibility into the process as a whole. ${ }^{26}$ In terms of

25. One commentator who worked as a consultant for BP conducting stakeholder consultation noted the lack of process in relation to such consultation. "They had no methodological guidelines, no framework, in essence nothing ... just simply a brief consultation with their stakeholders. And [they did] a selective editing job afterwards ... there were no criteria governing what they included or what they excluded from the report" (Macfarlane 2002: 32-33).

26. Some of the criticisms of the social accounting process noted by the verifier include the following: a Premier Oil employer was used as a translator; there was no formal method for selecting interviewees; the interviewees in a particular location were beneficiaries of Premier Oil community development programmes and did not include either any of those individuals who had participated in a demonstration or any fishermen "whose fishing grounds were allegedly disrupted by the construction" of the oil platform and were not sufficiently representative of the population in the area (Premier Oil 2001: 67 and 69). 
raising human rights issues, as noted above, the verifier commented on the fact that political repression in Myanmar would have necessarily compromised the stakeholder consultation process (Premier Oil 2002: 70).

\section{Transparency}

As with social reporting, the transparency of procedures and methodologies for gathering and verifying information is fundamental to the credibility and legitimacy of the verification process. Apart from Premier Oil's 2001 report, the verification reports of the four oil companies examined provide little detail of verification methodology. For example, in its verification of Talisman's CSR Report 2001, PwC does not disclose how stakeholders were selected for consultation or give much detail on how the consultation process was conducted apart from a questionable claim that "independent" translators were used (Talisman 2002: 6-7).

Ernst \& Young, in their verification statement in BP's 2001 report provide very little detail of methodology, but are more expansive in the 2002 report, listing which documents were reviewed and which operating sites were visited (BP 2003a: 30). Again, Premier Oil's Report sets a higher standard. The methodology of the social accounting process and the verification are set out in some detail (Premier Oil 2002: 12-17, 63).

\section{Independence}

Independence of verifiers is another important problem that emerges from a review of current verification practices. Private consulting/auditing firms often provide a range of services to clients that compromise their independence. The GRI-suggested criteria for selecting verifiers include, determining "an assurance provider's degree of independence and freedom from bias, influence, and conflicts of interest" and ensuring that such provider has "not been involved in the design, development or implementation of the organisation's sustainability monitoring and reporting systems or assisted in compiling the sustainability report" (GRI 2002: 77-78).

For Talisman's 2000 CSR Report, PwC not only conducted the stakeholder consultations and the audit process but also advised Talisman on the design and implementation of its CSR policies and processes (Talisman 2001: 10). Ernst \& Young is the financial auditor for BP and also verifies their Environmental and Social Report. While the firm does provide the service of writing reports for some clients, it does not, as a matter of principle, verify the reports it writes (Johnston 2002: 7).

Under the AA1000 Standard verifiers must make a public "Statement of Independence" that includes, a declaration of independence, disclosure of any conflict-of-interest policies and "[a]n account of any recent, ongoing or 
potential financial or commercial relationships" with the reporting company, including those of the individuals in the verification team. The verifier is also obliged to declare its impartiality in terms of Stakeholder interests and financial and commercial relationships with the Reporting Organisation (AA 2003: 25-27).

The verification of Premier Oil's 2001 Report by the Corporate Citizenship Unit (CCU) of Warwick Business School, University of Warwick, is also open to question on the issue of independence. Premier Oil retained a member of the Corporate Citizenship Unit as an advisor "on human rights and corporate social responsibility principles and targets" and in relation to the development of performance indicators and management tools for the evaluation of stakeholder feedback (Premier Oil 2002: 10). This relationship was acknowledged in both the reports and, in the 2002 Sustainability Report, the company took a further step of classifying the assurance provided by their verifier as a "second-party" audit. ${ }^{27}$ The company states that in future the reporting process and report will be verified by a third party (Premier Oil 2003: 11). As the verifier did not audit the social reporting process and no third party audit is yet available on Premier's website, it is likely that no third-party audit will be conducted on the 2002 report.

\section{Qualification of Verifiers}

A 1996 U.S. Department of Labor study of American textile companies revealed that where monitors were used to ensure compliance of supplier factories with corporate codes of conduct, while they had technical expertise in production and quality control they were "relatively untrained with regard to the implementation of labor standards" (Forcese 1997: 27). A recent analysis of $\mathrm{PwC}$ monitoring methods in the inspection of labour standards in overseas textile factories found serious flaws in $\mathrm{PwC}$ monitoring methodology, raising the issue of the competence of private consulting/auditing firms to conduct such monitoring (O'Rourke 2000).

Similar concerns arise with respect to the competence of private consulting/auditing firms to verify a corporation's social performance where international human rights standards and issues are in question. Avery argues that these firms may have a useful role to play regarding such verification "particularly in terms of ensuring that the process is correct

27. The reason given for this change is the allegedly "stronger link with Premier" of CCU advisor Alyson Warhurst in the latest reporting cycle. In an interview in August 2002, the verifier, Dr. Magnus Macfarlane stated that the independence issue had been very much debated in the pilot phase and that there was strict agreement that there would be no interference by those involved in an advisory role with the company in the verification process or report. He also noted, at that time, that the decision to have a third party verify the report in the next accounting cycle had already been made. 
and thorough, and that standards are applied uniformly". He points out, however, that such firms "do not have a level of expertise and experience in social issues that would enable them to be the primary assessor" in any verification of human rights issues (Avery 2000: 58).

Among other things, the AA1000 Standard requires that a team of verifiers should have the professional qualifications necessary, including "knowledge of specific aspects of performance and impact" such as human rights. Such individuals should also have experience in social and other verification and significantly "an [a]rea of expertise covering key dimensions of the information provided and the organisation's context and Stakeholders" (AA 2003: 27-29). This would suggest in the case of corporations operating in conflict zones or repressive regimes, that verification teams should include not only persons with training and experience in human rights impact assessment and stakeholder consultation methodology, but also a member with a legal background in international human rights and humanitarian law. One team member should also have training and experience in human rights investigation processes. Such experience should include participation in a human rights fact-finding mission conducted by an IGO such as the UN or its agencies, a state, or an international NGO such as Amnesty International or Human Rights Watch. Finally, the team should include a member with an in-depth knowledge of the social, political, cultural and economic context of the area where the business activity is taking place ${ }^{28}$.

There is no indication in Talisman's CSR Reports of the qualification of the members of the PwC audit teams to conduct interviews on the human rights dimension of Talisman's activities in Sudan. PwC declined numerous requests from the author for an interview and this issue was unable to be clarified. The verification of the 2001 Premier Oil report, on the other hand, was performed by an academic with expertise in verification methodology and social impact assessments (Macfarlane 2002: 32-33). Interviews with other practitioners conducting verifications of social and human rights performance reports reveal that in most cases verification teams have little or no expertise in international human rights or humanitarian law or training or experience in human rights investigation. Ernst \& Young noted that most of their social auditors had backgrounds in environmental concerns, while others had experience as political lobbyists (Johnston 2002: 12). ${ }^{29}$

28. I am indebted to Georgette Gagnon for these latter points.

29. A representative of ERM, a company that conducts social impact assessments and stakeholder consultation (not verification) for BP, Shell and other oil companies, stated that while the assessment teams do not include lawyers with training in international human rights law, they do have members from a wide variety of backgrounds including social sciences, such as anthropology, members drawn from local offices that have knowledge of the local cultural context and members knowledgeable about the human rights issues related to the investment in question (Selby 2002: 1-4). 


\section{CONCLUSION}

The preceding analysis identifies significant concerns about the adequacy and effectiveness of voluntary self-regulation regimes as a means to ensure that TNCs respect human rights in their extraterritorial activities. First, the format of the corporate and other voluntary instruments surveyed varies from a list of broad principles to more specific standards with implementation requirements and voluntary follow-up measures. Many of the human rights provisions that do exist are drafted in vague terms. Few of the instruments reviewed deal sufficiently with human rights issues relevant to corporate activity in conflict zones or repressive regimes. Only the UN Norms and the Global Compact address in any detail the issue of corporate complicity in human rights abuses, and all but the UN Norms are drafted in permissive language. In addition, none of the codes or policies, apart from the UN Norms, provide for any sort of effective compliance mechanisms such as provisions for independent monitoring, or requirements for credible reporting and verification of reports.

On the issue of social or human rights performance reporting, the GRI Guidelines are, on the whole, a very encouraging development. They have the legitimacy in the business and NGO communities due to widespread consultation on the development of the Guidelines with multiple stakeholders, and show a developing stringency of disclosure standards that offers real potential in the future. Nonetheless, it must be noted that the first board of directors of the GRI is heavily populated with representatives from business without corresponding numbers of NGOs or academics. The Guidelines also have several significant shortcomings. First, they do not provide indicators specific to a particular operating site or the operating environment of a particular company. Second, the lack of development of human rights indicators is unsatisfactory as it allows reporting companies to avoid addressing fundamental human rights issues related to their activities and still claim that their report is "in accordance" with the Guidelines. Finally, independent verification is not required for a report to be considered prepared "in accordance" with the Guidelines.

TNC practice in social performance reporting and verification raises important issues of credibility. More corporations now appear to be using the GRI guidelines, to some extent, in the production of their reports. In most cases however, their use has not appeared to improve the coverage of human rights information. Without accepted international and national standards on reporting methodologies and processes, corporations may collect and report information as they see fit, while promoting a rosy view of corporate activity, leaving even industry leaders in this area open to 
the criticism of "greenwashing". ${ }^{30}$ Equally, current verification practices can also be criticized because they lack credible mandates, verification methodologies, transparency of process, auditor independence and auditor expertise.

Apart from the UN Norms, the existing self-regulation regimes with their permissive and inadequate provisions, voluntary compliance, voluntary self-assessment and voluntary verification of such assessment, are at best minimalist and at worst ineffective in creating real accountability on the part of TNCs for complicity in violations of human rights associated with activity in conflict zones and repressive regimes. Thus, as Frey observes, it is "a company's goodwill, business culture, and knowledge of best practices [that] largely determine how it chooses to respond to human rights violations affecting its employees or other stakeholders" (Frey 1997: 180).

To be more effective in creating accountability and thereby protecting basic human rights, there must be a uniformity of standards based on international human rights and humanitarian law, such as those set out in the UN Norms. The provisions must create specific, well-defined mandatory human rights obligations applicable to corporate activity. For corporations active in conflict zones and repressive regimes, these codes and policies must at a minimum prohibit corporations from committing or benefiting from egregious violations of human rights and international humanitarian law such as forced displacement, forced labour, rape, extrajudicial murder or torture, to name a few.

They must also lay down stringent reporting and verification requirements. Companies should be required in their reports to set out the reporting methodology and to fully address in a balanced way the human rights issues related to the investment, as well as the impact of the investment within the broader human rights context. Verifiers should be given a broad enough verification mandate to allow them to fully assess the credibility of the information in the report, including the process by which information was gathered and selected for inclusion. They should also be required to assess the report in light of key human rights issues that have been raised about the company's activities and the political, cultural and social context within which the company is operating. Such reports should be publicly disclosed in their entirety and not subsequent to vetting by the company. Verification reports should also provide details of the verification methodology. Verification teams must be independent of the reporting company

30. The California Global Corporate Accountability Project notes that " $[\mathrm{g}]$ reenwashing takes many forms: sweeping claims of improvements without quantitative data; selective data that highlight improvements in one area ... while ignoring other crucial areas" (The California Global Corporate Accountability Project 2002: 16). 
in much the same way that financial auditors are now being required to be independent, and reports should include statements of independence and disclose any conflicts of interest the verifiers may have. Such teams should include, not only members with an expertise in social auditing such as AA1000 accreditation or rigourous training in social impact assessments, but also a lawyer with expertise in international human rights and humanitarian law, a member with hands on experience in human rights fact-finding and a member with an expertise in the political, social and cultural context of the state or area within which the company is operating.

Finally, such codes or principles must require periodic independent monitoring of corporate conduct. Such monitoring could be conducted instead of, or in addition to, reporting and verification. Monitoring teams, should be composed of members with expertise similar to that suggested for verifiers. Monitors should be fully independent of the company they are monitoring and the host government of the country where the company is operating. Direct payment of monitoring teams by companies could compromise the independence of monitors. Thus, where monitors are not IGOs, such as UN Special Rapporteurs, codes or policies should ideally provide for a monitoring fund to which the company contributes, that can be managed by a third party such as a home state government agency.

It is unlikely that these reforms will be adequately addressed by the private sector. They have neither the expertise nor the requisite public interest. Moreover, given that corporations are legal persons created for profit maximization, the voluntary aspect of such self-regulation, even if reformed, is likely to remain problematic where human rights 'obligations' conflict with "the incentive to make a profit and remain competitive" (Macek 2002: 124). There is no doubt that voluntary self-regulation can serve a useful purpose (Government of Canada 1998: 4-6). Indeed the trend of voluntary self-regulation in this area may help in developing consensus in the business community and among states for international regulation of TNC conduct. However, stronger and more immediate action is needed to ensure the accountability of corporations operating in areas where complicity in grave violations of human rights is likely. Thus, while keeping pressure on the private sector to continue to improve their voluntary codes and practices, it will be important to lobby governments to take domestic action to incorporate extraterritorial regulatory measures, based on the reforms suggested above, into a mandatory legislative framework. In addition, emphasis should be placed on building state and private sector consensus around 'international' multistakeholder and intergovernmental initiatives, such as the UN Norms, to ratchet up the global standard of conduct expected of TNCs and lay the foundation for international regulation. 


\section{REFERENCES}

AcCountAbility (AA). 2003. Assurance Standard AA1000. Cited at: http://www. accountability.org.uk/resources/default.asp (visited August 18, 2003).

AMNESTY InTERNATIONAL. 2000. Sudan: The Human Price of Oil. Cited at: http:// web.amnesty.org/ai.ngf/index/AFR540042000.htm (no longer posted).

AVERy, Christopher. 2000. Business and Human Rights in a Time of Change. London: Amnesty International.

Bernard, Elaine. 1997. "Ensuring Monitoring is not Coopted." New Solutions, Vol. 7 (cited in Avery 2000: 50-51).

BoyD, Alan. 2003. "Multinationals and Accountability." Asia Times, August 19. Cited at: http://www.atimes.com/atimes/Global_Economy/EH19Dj01. html (visited August 24, 2003).

British Petroleum (BP). 2000. Finding Your Way Through the Maze: Ethical Conduct Policy: Guidelines on Business Conduct.

British Petroleum (BP). 2002a. Business Policies. Cited at: http://www. bp.com/files/33/3461PolicyQ4.qxd_339.pdf (visited August 21, 2003).

British Petroleum (BP). 2003a. Environmental and Social Review 2002. Cited at: http://www.bp.com/files/17/BP_ENV_SOC_2002_1723.pdf (visited August 25, 2003).

British Petroleum (BP). 2003b. Location Report: Angola. Cited at: http:// www.bp.com/location_rep/angola/stakeholder/process.asp (visited August $25,2003)$.

Brownlie, Ian. 1983. System of the Law of Nations: State Responsibility, Part I. Oxford: Clarendon Press.

Canadian Democracy and Corporate Accountability Commission. 2002. The New Balance Sheet: Corporate Profits and Responsibility in the $21^{s t}$ Century. Cited at: http://www.corporate-accountability.ca (visited August 18, 2003).

CASSEL, Douglass. 1996. "Corporate Initiatives: A Second Human Rights Revolution?” Fordham International Law Journal, Vol. 19, 1963-1984.

CLAIHR. 2000. "Complicity Backgrounder: Options Available to the Government of Canada in Responding to Canadian Corporate Complicity with Human Rights Abuses." Cited at: http://www.claihr.org/publications_docs/project_documents/business/1corpcomp.pdf (visited January 17, 2004).

Clapham, Andrew. 2000. "The Question of Jurisdiction under International Criminal Law over Legal Persons: Lessons from the Rome Conference on an International Criminal Court." Liability of Multinational Corporations under International Law. M. T. Kamminga and S. Zia Zarifi, eds. The Hague, London and Boston: Kluwer Law International, 139-195.

Clapham, Andrew and Scott Jerbi. 2001. "Categories of Corporate Complicity in Human Rights Abuses." Hastings International and Comparative Law Review, Vol. 24, 339-349. 
CRAWFORD, James. 2002. The International Law Commission's Articles on State Responsibility: Introduction, Text and Commentaries. Cambridge and New York: Cambridge University Press.

DanaILOv, Silvia. 1998. "The Accountability of Non-State Actors for Human Rights Violations: The Special Case of Transnational Corporations." Geneva. Cited at: http://www.humanrights.ch/buildungarbeit/seminare/ pdf/000303_danailov_studie.pdf (visited January 8, 2004).

Doe v. Unocal Corp. 248 F.3d 915 ( $9^{\text {th }}$ Cir. 2002).

FEENEY, Patricia. 2002. "Making Companies Accountable: An NGO Report on Implementation of the OECD Guidelines for Multinational Enterprises by National Contact Points." Rights and Accountability in Development. Cited at: www.oecd.org/dataoecd/16/37/2965489.pdf (visited January 21, 2004).

FeEney, Patricia, et al. 2003. "Open Letter to National Contact Points for the OECD Guidelines Regarding the Followup to the UN Panel of Experts Final Report on the Illegal Exploitation of the Natural Resources and other Forms of Wealth of the Democratic Republic of the Congo." Monday, December 15.

FORCESE, Craig. 1997. Commerce with a Conscience? Human Rights and Corporate Codes of Conduct. Montreal: International Centre for Human Rights and Democratic Development.

FORCESE, Craig. 2002. "Globalizing Decency: Responsible Engagement in an Era of Economic Integration." Yale Human Rights and Development Law Journal, Vol. 5, 1-55.

Freeman, Alan. 2004. "Nigeria Oil Thefts Pose a Challenge for Shell." The Globe and Mail. Wednesday, January 7, B12.

FREY, Barbara. 1997. "The Legal and Ethical Responsibilities of Transnational Corporation in the Protection of International Human Rights." Minnesota Journal of Global Trade, Vol. 6, 153-188.

GagnON, Georgette and John RYLE. 2001. Report of an Investigation into Oil Development, Conflict and Displacement in Western Upper Nile, Sudan. October 2001. Cited at: http://www.ideationconferences.com/sudanreport2001/SudanReportfinal101101.pdf (visited January 15, 2004).

Gagnon, Georgette, Audrey Macklin, and Penelope Simons. 2003. Deconstructing Engagement: Corporate Self-Regulation in Conflict Zones: Implications for Human Rights and Canadian Public Policy. Cited at: http:// www.law.utoronto.ca/documents/Mackin/DeconstructingEngagement.pdf (visited August 23, 2003).

Global Reporting InItIATIVE (GRI). 2002. 2002 Sustainability Reporting Guidelines. Cited at: http://www.globalreporting.org (visited August 18, 2003).

Global RePorting Initiative (GRI). 2003. "UN Global Compact and GRI 2002 Guidelines.” Cited at: http://www.globalreporting.org.news/PR/030319.asp (visited August 22, 2003). 
Global Sullivan PrinciPles Website. Cited at: http://globalsullivanprinciples. org (visited January 8, 2004).

Government of CAnAdA. 1998. Voluntary Codes: A Guide for Their Development and Use. Cited at: http://strategis.ic.gc.ca/SSG/ca00863e. html (visited August 18, 2003).

Government of CANADA. 2003. "Annual Report 2003: Canada's National Contact Point for the OECD Guidelines for Multinational Enterprises." Cited at: http://www.ncp-pcn.gc.ca/annual_2003-en.asp (visited January 15, 2004).

HABBARD, Anne-Christine. 2001. "The Integration of Human Rights in Corporate Principles." OECD Guidelines Annual Report 2001, 99-102. Cited at: http://www.oecd.org/findDocument/0,2350,en_2649_34889_1_ 119687_1_1_37439,00.html (visited August 18, 2003).

HARKER, John. 2000. Human Security in Sudan: Report of Canadian Assessment Mission. Ottawa: Minister of Foreign Affairs.

Human Rights Research and Education Centre Website. Cited at: http:// www.cdp-hrc.uottawa.ca/globalization/busethics/codeint.html (visited August 17, 2003).

Human Rights Watch. 1998. "Columbia: Human Rights Concerns Raised by the Security Arrangements of Transnational Oil Companies (April 1998)." Cited at: http://www.hrw.org/advocacy/corporations/colombia/Oilpat.htm (visited January 8, 2004).

Human Rights Watch. 1999. The Price of Oil: Corporate Responsibility and Human Rights Violations in Nigeria's Oil Producing Communities. Cited at: http://hrw.org/reports/1999/nigeria/Nigew991-01.htm (visited January 7, 2004).

Human Rights Watch. 2003a. Human Rights Watch World Report 2003. New York, Washington, London, Brussels: Human Rights Watch, 201-207.

Human Rights Watch. 2003b. Sudan, Oil and Human Rights. Cited at: http:// www.hrw.org/reports/2003/sudan1103/sudanprint.pdf (visited January 15, 2004).

International Council on Human Rights Policy. 2002. Beyond Voluntarism: Human Rights and the Developing International Legal Obligations of Companies. Versoix, Switzerland.

JANus. 2002. "Core? What a Scorcher!" Ethical Corporation Magazine, July. Johnston, Doug. 2002. Ernst \& Young, London. Telephone Interview. June $5^{\text {th }}$.

JosEPH, Sarah. 1999. "Taming the Leviathans: Multinational Enterprises and Human Rights." Netherlands International Law Review, Vol. 46, 171-203.

KAMmingA, Menno and Saman ZIA-ZARIFI. 2000. "Liability of Multinational Corporations under International Law: An Introduction." Liability of Multinational Corporations under International Law. M. T. Kamminga and S. Zia Zarifi, eds. The Hague, London and Boston: Kluwer Law International, 1-13. 
MaCalister, Terry. 2000. "Premier Admits Abuses in Burma." The Guardian. Tuesday, May 16. Cited at http://www.guardian.co.uk/Archive/Article/0, 4273,4018615,00.html (visited January 8, 2004).

Macfarlane, Magnus. 2002. Fellow at the Corporate Citizenship Unit of the Warwick Business School, University of Warwick. Telephone Interview. August $9^{\text {th }}$.

MACEK, Erin Elizabeth. 2002. "Scratching the Corporate Back: Why Corporations Have No Incentive to Define Human Rights." Minnesota Journal of Global Trade, Vol. 11, 101-124.

MACKLIN, Audrey. 2003. "Our Sisters from Stable Countries: War, Globalization, and Accountability." Social Politics, Vol. 10, 256-283.

MaItLAND, Alison. 2003. "Companies Ready to Work with UN Human Rights Code." Financial Times, December 8. Cited at: http://financialtimes.com (visited December 16, 2003).

MAYNe, Ruth. 1999. "Regulating TNCs: The Role of Voluntary and Governmental Approaches." Regulating International Business: Beyond Liberalization. S. Picciotto and R. Mayne, eds. Houndmills, Basingstoke: Macmillan Press and New York: St. Martins Press, 235-254.

McCorquodale, Robert. 2002. "Human Rights and Global Business." Commercial Law and Human Rights. S. Bottomley and D. Kinley, eds. Aldershot; Burlington: Ashgate Dartmouth, 89-114.

MeERAN, Richard. 2003. "Corporations, Human Rights and Transnational Litigation." Lecture delivered at the Monash University Law Chambers, January $29^{\text {th }}$. Cited at: http://www.law.monash.edu.au/castancentre/ events/2003/meeranpaper.html (visited January 21, 2004).

MuchlinsKi, Peter. 2001. "Human Rights and Multinationals: Is There a Problem?" International Affairs, Vol. 77, 31-48.

O'Rourke, Dara. 2000. "Monitoring the Monitors: A Critique of PricewaterhouseCoopers (PwC) Labour Monitoring." Cited at: http://web. mit.edu/dorourke/www/PDF/pwc.pdf.

OECD. 2000a. "The OECD Guidelines for Multinational Enterprises." OECD Declaration and Decisions on International Investment and Multinational Enterprises: Basic Texts. Directorate for Financial, Fiscal and Enterprise Affairs, Committee on International Investment and Multinational Enterprises, DAFFE/IME, Annex 1.

OECD. 2000b. "The OECD Guidelines for Multinational Enterprises: Text Commentary and Clarifications." Working Party on the OECD Guidelines for Multinational Enterprises, Directorate for Financial, Fiscal and Enterprise Affairs, Committee on International Investment and Multinational Enterprises, DAFFE/IME/WPG(2000)15/FINAL.

OECD. 2000c. "OECD Proceedings: Non-Member Economies and the OECD Guidelines for Multinational Enterprises." Paris: OECD Directorate for Financial, Fiscal and Enterprise Affairs. Cited at: http://www.oecd.org/ pdf/M00020000/M00020571.pdf (visited December 3, 2002). 
OECD. 2001a. "The OECD Guidelines for Multinational Enterprises and Global Instruments for Corporate Responsibility: Background and Issues Paper." Directorate for Financial, Fiscal and Enterprise Affairs. Cited at: http://www.oecd.org/pdf/M00003000/M00003658.pdf (visited December $3,2002)$.

OECD. 2001b. "TUAC Survey of the Functioning of National Contact Points." OECD Guidelines Annual Report 2001. Paris: OECD, 37-44.

OECD WATCH. 2003. "Review of National Contact Points: June 2002-June 2003." Cited at: http://www.germanwatch.org/tw/kw-inl02.pdf (visited January 15, 2004).

Osborn, Andrew. 2001. "British Oil Firms Accused of Burma Abuses." The Guardian. Friday, October 12. Cited at: http://www.guardian.co.uk/ print/0,3858,4275499-103681,00.html (visited January 8, 2004).

Premier Oil. 2002. Social Performance Report 2001. Cited at: http://www. premier-oil.com/asp/pdf/PO-SP-Final.pdf (visited August 18, 2003).

PREMIER OIL. 2003. Sustainability Performance Report 2002. Cited at: http:// www.premieroil.com/asp/uploads/uploadedfiles/1/114/premieroil_sust_ rep_03.pdf (visited August 21, 2003).

Presbyterian Church of Sudan v. Talisman Energy, Inc. 244 F. Supp. 2d 289 (S.D.N.Y. 2001).

RAMASASTRY, Anita. 2002. "Corporate Complicity: From Nuremberg to Rangoon: An Examination of Forced Labor Cases and Their Impact on the Liability of Multinational Corporations.” Berkeley Journal of International Law, Vol. 20, 91-159.

RATNER, Steven. 2001. "Corporations and Human Rights: A Theory of Legal Responsibility." Yale Law Journal, Vol. 111, 443-545.

Royal Dutch/Shell. 2002a. "Statement of General Business Principles." Governance in Shell, $2^{\text {nd }}$ ed. (CD Compilation).

Royal Dutch/ShEll. 2002b. "Management Primer." Governance in Shell, $2^{\text {nd }}$ ed. (CD Compilation).

Royal Dutch/Shell. 2002c. People, Planet and Profits: The Shell Report 2001. Cited at: http://www.shell.com/html/investor-en/shellreport01/reports2001 (visited August 25, 2003).

Royal Dutch/Shell. 2003. Meeting the Energy Challenge: The Shell Report 2002. Cited at: http://www.shell.com/home/Framework?siteId=shellrepo rt2002-en $\& F C 1=\& F C 2=/ L e f t H a n d N a v ?$ LeftNavState $=4,2 \& F C 4=\& F C 5$ $=\&$ FC3 3 /shellreport2002-en/html/iwgen/about_shell/how_we_work.html (visited August 21, 2003).

Royal Dutch/Shell. "Our Approach to Human Rights." Cited at: http://www. shell.com/home/Framework?siteId=royal-en $\& F C 1=\& F C 2=\& F C 4=\& F C$ 5=\&FC3=/royal-en/html/iwgen/Issues/human_rights/our_approach_to_ human_rights.html (visited August 21, 2003).

SAI WeBsiTE. Cited at: http://www.cepaa.org/AboutSAI/AboutSAI.htm (visited January 20, 2004). 
SELBY, Sarah. 2002. Consultant, Social Strategies, ERM, U.K. Telephone Interview, July $29^{\text {th }}$.

Statement by the Governments of the United States of America and UNITED KINGDOM. 2000. Cited at: http://www.unglobalcompact.org/un/gc/ unweb.nsf/webprintview/volsupport.htm (no longer posted).

TAlisman EnERgy InC. 2001. Corporate Social Responsibility Report 2000: Sudan Operations. Cited at: http://www.talisman-energy.com/pdfs/ csr2000_report.pdf (visited August 18, 2003).

TAlisman Energy InC. 2002. Corporate Social Responsibility 2001. Cited at: http://www.talisman-energy.com/pdfs/csr2001_report.pdf (visited August 18, 2003).

TAlisman EnERgy Inc. 2003. 2002 Corporate Social Responsibility Report. Cited at: http://www.talisman-energy.com/pdfs/TLM02CR.pdf (visited August 18, 2003).

Talisman Energy Inc. "Policy on Business Conduct." Cited at: http://www. talisman-energy.com/socialresponsibility/governance/business_conduct. html (visited August 18, 2003).

Talisman Energy Inc. "Sudan Operating Principles.” Cited at: http://www. talisman-energy.com/socialresponsibility/governance/sudan.html (visited August 18, 2003).

TAlisman EnERGy Website. Cited at: http://www.talisman-energy.com/operatingareas/sudan/sudan.html (visited August 20, 2003).

The California Global Corporate Accountability Project. 2002. Beyond Good Deeds: Case Studies and a New Policy Agenda for Corporate Accountability. Nautilus Institute for Security and Sustainable Development, The Natural Heritage Institute, and Human Rights Advocates.

TofToy, Ryan P. 1998. "Now Playing: Corporate Codes of Conduct in the Global Theater. Is Nike Just Doing It?" Arizona Journal of International and Comparative Law, Vol. 15, 905-929.

UN Global Compact. 2003. The Global Compact Report on Progress and Activities: July 2002-July 2003. Cited at: http://www.unglobalcompact. org (visited August 25, 2003).

UN Global COMPACT WeBsite. Cited at: http://www.unglobalcompact.org:80/ content/AboutTheGC/TheNinePrinciples (visited January 7, 2004).

United NATIONS (UN). 1995. The Realization of Economic, Social and Cultural Rights: The Relationship between the Enjoyment of Human Rights, in particular, International Labour and Trade Union Rights, and the Working Methods and Activities of Transnational Corporations. UN Doc. E/CN.4/ Sub.2/1995/11.

United Nations (UN). 1999. "Secretary-General Proposes Global Compact on Human Rights, Labour, Environment, In Address to World Economic Forum in Davos." Press Release UN Doc. SG/SM/6881, 1 February 1999. Cited at: http://www.un.org/News/Press/docs/1999/19990201.sgsm6881. html (visited January 7, 2004). 
United NATIONS (UN). 2000. Situation of Human Rights in Myanmar (interim report). UN Doc. A/55/359.

United NAtions (UN). 2002a. Question of the Violation of Human Rights and Fundamental Freedoms in any Part of the World: Report on the Situation of Human Rights in Myanmar. UN Doc. E/CN.4/2002/45.

United Nations (UN). 2002b. Human Rights Principles and Responsibilities for Transnational Corporations and Other Business Enterprises, Introduction. UN Doc. E/CN.4/Sub.2/2002/XX/Add.1, E/CN.4/Sub.2/2002/WG.2/WP.1/ Add.1 (February 2002 for discussion in July/August 2002).

United Nations (UN). 2002c. Draft Fundamental Human Rights Principles for Business Enterprises, Addendum 1. UN Doc. E/CN.4/Sub.2/2002/X/Add.1, E/CN.4/Sub.2/2002/WG2/WP.1/Add.1 (Draft for Discussion November 2001). Cited at: http://www1.umn.edu/humanrts/links/omig.html (visited August 18, 2003).

United Nations (UN). 2003a. Draft Norms on the Responsibilities of Transnational Corporations and Other Business Enterprises with Regard to Human Rights. UN Doc. E/CN.4/Sub.2/2003/12/Rev.2 (2003).

UNITED NATIONS (UN). 2003b. Commentary on the Norms on the Responsibilities of Transnational Corporations and Other Business Enterprises with Regard to Human Rights. UN Doc. E/CN.4/Sub.2/2003/38/Rev.2 (2003).

United NATIONS (UN). 2003c. Responsibilities of Transnational Corporations and Other Business Enterprises with Regard to Human Rights. SubCommission Resolution 2003/16. UN Doc. E/CN.4/Sub.2/2003/L.11 at 52 (2003).

United Nations (UN). 2003d. Joint Statement Submitted by the International Chamber of Commerce and the International Organization of Employers, non-governmental organizations in general consultative status. UN Doc. E/CN.4/Sub.2/2003/NGO/44 (2003).

United Nations Environment Programme Website. Cited at: http://www. uneptie.org/outreach/reporting/gri.htm\#background (visited January 8, 2004).

U.K. Parliament. 2003. Bill 129. Corporate Responsibility Bill. Cited at: http://www.foe.co.uk/campaigns/corporates/core/about/bill.html (visited January 21, 2004).

U.S. DePartment of State. 2001. Voluntary Principles on Security and Human Rights. Fact Sheet. Released by the Bureau of Democracy, Human Rights and Labor. Cited at: http://www.state.gov/g/drl/rls/2931.htm (visited August 22, 2003).

U.S. Department of State. 2003. Country Reports on Human Rights Practices - 2002. Bureau of Democracy, Human Rights, and Labor.

WADDELL, Steve. 2002. "The Global Reporting Initiative: Building a Corporate Reporting Strategy Globally." Global Action Network Net. Cited at: http:// www.gan-net.net/pdfs/gri.pdf (visited January 8, 2004).

Weissbrodt, David. 2000. "The Beginning of a Sessional Working Group on Transnational Corporations Within the U.N. Sub-Commission on 
Prevention of Discrimination and Protection of Minorities." Liability of Multinational Corporations under International Law. M. T. Kamminga and S. Zia-Zarifi, eds. The Hague, London and Boston: Kluwer International Law, 119-138.

WeIsSBRodT, David. 2003. E-mail communication. August $19^{\text {th }}$. Wiwa v. Royal Dutch Petroleum Co. 226 F.2d 88 (2d Cir. 2000).

\section{RÉSUMÉ}

\section{Volontarisme d'entreprise et droits humains : la pertinence et l'efficacité des régimes d'autorégulation volontaire}

En l'absence de responsabilité légale interne et internationale des entreprises transnationales en matière d'abus au plan des droits humains dans leurs activités outre-mer, les gouvernements, les entreprises et les ONG ont encouragé le développement et la mise en œuvre de régimes d'autorégulation volontaire. Cependant, les détracteurs de ces mesures volontaires soutiennent que leur capacité de réglementer l'activité des entreprises et de solutionner les enjeux qui y sont liés en termes de droits humains est demeurée inadéquate. Plus précisément, cet essai remet en cause le caractère approprié ou non de ces régimes volontaires et leur efficacité à prévenir une certaine complicité des entreprises dans des situations de violation évidente des droits humains, reliées à leurs activités dans des zones de conflits et sous des régimes répressifs.

L'étude recense et évalue les codes et les politiques de quatre entreprises pétrolières multinationales, en plus des codes développés par l'industrie, les organismes intergouvernementaux et les initiatives des multidétenteurs d'intérêts. Elle examine aussi les pratiques d'entreprises associées à l'emploi de ces instruments, laissant entrevoir des problèmes importants au plan de leur nature volontaire, de leur langage, de leur contenu en termes de droits humains et des mécanismes d'acquiescement.

La configuration des codes et des politiques étudiés varie beaucoup, en passant d'une liste de principes généraux à des normes plus précises, et comporte parfois des exigences de mise en œuvre et des mesures volontaires de suivi. Peu de ces instruments traitent suffisamment des enjeux en termes de droits humains. Seulement les Nations Unies avec le développement de leurs «Normes sur la responsabilité en matière de droits de l'homme des sociétés transnationales et autres entreprises » et l'organisme Global Contact ont abordé dans le détail l'enjeu de la complicité dans les abus au 
plan des droits humains, et toutes les normes, sauf celles des Nations Unies, sont formulées dans un langage permissif. De plus, aucun de ces codes et aucune de ces politiques, excluant les normes de l'ONU, ne présentent des mécanismes de respect efficaces.

En jetant un coup d'œil sur les pratiques qui se développent chez les multinationales pour rendre compte de leur performance en matière de droits humains et sociaux, on constate que peu d'entreprises semblent avoir mis au point un cadre de comptabilité sociale transparente et fiable selon des procédures et une méthodologie qui offrent une garantie d'exactitude au plan de la cueillette de données liées aux droits humains. Souvent, il n'existe aucune divulgation du processus qui encadre la sélection et la consultation des détenteurs d'intérêts, de la façon dont la consultation de ces derniers fournit une information sur les frontières, l'envergure et le contenu d'un rapport en particulier, ou bien de la manière dont les décisions sont prises sur ce qui entre ou n'entre pas dans un rapport. Enfin, on observe une tendance marquée chez les entreprises transnationales à donner un bilan positif du progrès et de la performance des entreprises, nonobstant la divulgation sporadique de leurs forces et de leurs faiblesses.

En ce qui concerne la question de la reddition des comptes en matière de performance sociale, les Lignes directrices de la Global Reporting Initiative (GRI) pour le reporting développement durable de 2002 constituent dans l'ensemble un développement encourageant. Elles possèdent une légitimité dans la communauté des affaires et des ONG due à la large consultation dont elles ont fait l'objet au moment de leur élaboration et elles prévoient une sévérité croissante au plan des normes de divulgation qui présentent un potentiel réel pour l'avenir. Néanmoins, ces directives comportent aussi d'importantes faiblesses. En premier lieu, elles ne fournissent pas d'indicateurs spécifiques pour un site particulier d'exploitation ou pour un environnement d'activités d'une entreprise en particulier. Deuxièmement, l'absence d'élaboration d'indicateurs de droits humains engendre une situation insatisfaisante en permettant aux compagnies qui font rapport d'éviter de traiter des enjeux fondamentaux des droits humains liés à leurs activités et de prétendre que leur rapport est conforme aux directives. Enfin, une vérification indépendante n'est pas exigée pour qu'un rapport soit considéré en accord avec les directives.

Les pratiques courantes de vérification sont aussi l'objet de préoccupations sérieuses. Tout comme dans le cas de la divulgation sociale, il n'y a pas de normes universelles acceptées pour fins de vérification sociale, quoique des normes volontaires privées soient en élaboration. Sans normes obligatoires de vérification, les mandats de vérification sont donnés par les multinationales elles-mêmes. Alors, l'envergure de la vérification varie selon les compagnies et les préoccupations sérieuses à l'endroit des droits humains 
en relation avec les activités des entreprises ne sont pas abordées, sauf à la discrétion des multinationales elles-mêmes. Elles ne sont probablement pas soulevées par les vérificateurs dans tout rapport soumis au public.

Les rapports de vérification ont tendance à manquer de transparence au plan des procédures et de la méthodologie de cueillette et de vérification de l'information. L'impartialité des vérificateurs devient une autre préoccupation majeure puisque plusieurs entreprises privées de consultation et de vérification fournissent également des services-conseils aux multinationales dont elles assurent la vérification des livres. La fiabilité des rapports est en plus minée due au fait que la plupart des entreprises de vérification et de consultation ne possèdent pas l'expertise nécessaire en matière de cueillette et de divulgation d'information sur les droits humains.

Les normes des Nations Unies mises à part, les régimes actuels d'autorégulation, de par leurs dispositions inadéquates et permissives, leur respect volontaire, leur auto-évaluation et la vérification volontaire de cette évaluation, sont au mieux minimalistes et tout au plus inaptes à créer une reddition réelle de comptes en matière de droits humains de la part des entreprises transnationales qui œuvrent dans des zones de conflits ou sous des régimes répressifs.

De tels codes et politiques pourraient être modifiés de façon importante en précisant des obligations bien définies en matière de droits humains, une divulgation contraignante et des normes obligatoires de vérification, de même que des exigences de contrôle indépendant. Cependant, il ne faut pas s'attendre à ce que de telles réformes soient adéquatement abordées par le secteur privé. Le volet volontaire de ces pratiques et de ces outils demeurera probablement problématique là où les obligations entrent en conflit avec des préoccupations de profitabilité et de concurrence à l'échelle mondiale. C'est pourquoi, en plus d'encourager l'amélioration de ces codes, il serait également important d'exercer une pression sur les gouvernements pour qu'ils adoptent à l'interne des mesures législatives dictant la conduite à suivre de la part des entreprises dans les zones de conflits ou sous les régimes répressifs, des mesures fournissant un support aux initiatives de l'ordre de celles des normes des Nations Unies qui paveront les fondements d'une réglementation à l'échelle internationale. 